\title{
LEGAL AID CLINICS IN LESS THICKLY POPULATED COMMUNITIES
}

\author{
John S. Bradway*
} EGAL aid work, whether performed by independent societies, ${ }^{1}$ or
by clinics connected with law schools, ${ }^{2}$ has ceased to be a novelty in large cities, especially in the northeastern and extreme western parts of the United States. When one comes to examine the progress of this charitable aspect of law practice in less thickly settled communities, a definite orientation is necessary. There is little literature dealing either with the need in rural sections and the smaller cities for definite organizations or the question as to whether there is enough clinical material to make possible a law school course in this field. ${ }^{8}$ So the opening on October Ist, I93 I, of the legal aid clinic at Duke University inaugurated a most interesting experiment.

* Professor of Law, Duke University School of Law. Chairman, Legal Aid Committee of the Pennsylvania Bar Association; Secretary, National Association of Legal Aid Organizations. A.B., A.M., Haverford; LL.B., Pennsylvania. Co-editor and editor of various volumes of The Annals of the American Academy of Political and Social Science. Author, Laws of Pennsyivania Relating to Social WORK, LAW AND SOCIAI WORK, etc., and of various articles in periodicals on the subject of legal aid. $-E d$.

${ }^{1}$ On the general subject of legal aid work, see the following publications: R. H. Smith, Justrce and the Poor, The Carnegie Foundation, New York, I9I9; J. M. Maguire, The Lance of Justice, Harvard University Press, 1928; Smith and Bradway, The Growth of Legal Aid Work in the United States, Bulletin No. 398 of the U. S. Bureau of Labor Statistics (1926); The Annals of The American Academy of Political and Social Science: "Legal Aid Work," Vol. 124 (March, 1926), "The Progress in the Law," Vol. 136 (March, 1928), "Law and Social Weifare," Vol. I45 (Sept., I929); W. F. Willoughby, Principles of Judicial Administration, Part VI, p. 569 ff., The Brookings Institution, Washington, 1929 .

2 On the general subject of the work of legal aid clinics, for the earlier material see footnotes collected by the present writer for the following: I 3 ST. Lours L. REv. 122 ff. (I928); 2 So. Cax. L. Rev. 128, 252 (1929); 3 So. CaL. L. Rev. I73, 320, 384 (1930); 4 So. CaI. L. Rev. IO3 (1930); 79 U. of PA. L. Rev. 549 (193I); 5 So. CaL. L. Rev. 36 (I93I). For a recent description of the Harvard Legal Aid Clinic see Tilford E. Dudley, "The Harvard Legal Aid Bureau," I7 A. B. A. J. 692 (I93I); also, Bradway and Wheaton, "Legal Aid Organizations and Their Connections with Law Schools and Students," I6 A. B. A. J. 453 (I930).

${ }^{3}$ The only literature bearing directly on the subject with which the writer has come in contact is as follows: Alice Waldo, "The Need of Legal Aid in Ithaca and Tomkins County," a thesis presented to the Faculty of the Graduate School, Cornell University, for the degree of Master of Arts, February, 1931; M. Alice Hill, "Legal Aid in the Smaller Cities," The Annals of the American Academy of Political 
Duke University is located about three miles west of the industrial city of Durham, North Carolina. The population of the city is a little over 50,000, having doubled in the last ten years. The University itself has a population of between 2,800 and 3,000; the state of North Carolina is reported by the 1930 census to contain about $3,170,000$ persons. There are five or six cities in the state in the 50,000 class but it is predominantly agricultural. ${ }^{4}$ There was nothing on which to base a prediction as to the availability of clinical material, and, except for the legal aid clinic operated by the students of the University of Wisconsin in connection with the Madison Legal Aid Society, no comparable situations existed. Some suggestions appeared in connection with the reports of legal aid committees of State Bar associations but they gave little light; ${ }^{5}$ so that the undertaking had to be organized very largely on faith.

Preliminary predictions of failure were not wanting. The alleged conservatism of the South towards new ideas, the apprehensions of the local bar concerning competition for business, the difficulties encountered by strangers coming into any section of the country to start something new, the racial problem - these and a hundred possible obstacles appeared in the offing. The actual difficulties were somewhat different. They may be grouped under three heads: ( $I$ ) those arising because of the geographical situation, (2) those arising because of the

and Social Science, March, 1926, p. 59; Margaret B. Hay, "Law and Social Work in a Rural Community," The AnNals, September, r929, p. 137.

4 James MacClamroch, Jr., of the Greensboro Bar, made the following statement in an address before the North Carolina Bar Association in I930 ( 32 N. C. Bar Ass'n. Rep. 195):

"In the sense that there are no very large centers of population in the state, North Carolina may be said to be still largely a rural or at least a small town state. For this reason there are no very large law firms in the state. Those numbering five lawyers can probably be counted on one hand, and those numbering half a dozen can certainly be. If there be a firm of over half a dozen in the state I am not aware of it. As a consequence there is practically no absorption of fledgling barristers as they leave law school to enter the practice. They do not become apprenticed to a large firm as is usually the case in New York City where the firms often run as large as fifty or more men and the youngster is given a desk or table in the firm library and cloistered there for a year or so looking ap law and preparing briefs. On the contrary with us probably ninety-five out of every hundred or even a larger percentage of the young men and women admitted to the profession in North Carolina of necessity start out for themselves and weather the so-called starving period alone."

${ }^{5}$ See in particular the reports of the legal aid committees of the Illinois, Michigan, and Pennsylvania Bar Associations: 1925 Proceedings, Illinois State Bar Association 231; 1927 ibid. 298; 1928 ibid. 285; 1929 ibid. 230; 1930 ibid. 224.

See also Joel D. Hunter, "The Illinois Plan," The AnNals, March, I 926, p. I49. 
social condition of the community, and (3) those arising because of the problems of the legal profession.

\section{Organization Problems}

The range of drawing power was the first question. Obviously, if 50,000 people live within the radius of a mile from a given point, it will be easier for them to reach that point than if they are scattered over a larger circle. As was to be expected, cases came from nearby, but it became apparent almost at once that while cases came in from the University student body and from the inhabitants of Durham three miles away, they also came from Raleigh thirty miles off, from Wilson one hundred miles distant, from Charlotte one hundred and fifty miles to the west, and from cities outside the state. In the first couple of months requests for aid came in by mail from South Carolina, Virginia, New Hampshire, Pennsylvania, Colorado, and California. One even arrived from the Poor Persons' Committee of the Law Society in London. The problem then was to build up a machinery which could care for applications from a wide sweep of country and at the same time allow the personal contacts necessary between attorney and client. Through the state bar and local bar associations this statewide machinery is now being built up. Distance is a surmountable obstacle in conducting legal aid work.

The second difficulty lay in the attitude of the community towards asking legal advice. It appeared that the colored population had various specific contacts with members of the white race. Many troubles which a man in a large city would take to a lawyer or a legal aid society appeared customarily to be solved by laymen. Certain groups, even in the white section of the community, had not formed the general habit of consulting members of the bar. Whether this is true of all the less thickly settled communities or not it is impossible to say, but it was interesting to note the rate at which knowledge of the purposes of the clinic filtered down from the well informed members of the community to those less well posted on current matters.

Of course, allowance had to be made for the undoubted fact that no one trusts a lawyer merely because he hangs out a shingle. Probably many persons held back because they did not want to be the subject of enthusiastic but perhaps ill-considered experiments on the part of law students. That every law office must win its spurs in the actual conduct of cases and that satisfied clients are the best possible advertisement are as true of clinic work as of general practice. In the smaller community the citizen has not become so accustomed as has his urban 
brother to relying on organizations to do work for him. His contacts are more individual. The clinic must become part of local thinking; and only time, patience, and tact will accomplish that.

The third problem deals with the attitude of the legal profession. Obviously, in a community with a bar of some fifty or sixty members, among whom may be found much the same grades of success as occur in the large cities, a new lawyer starting business is a more impressive figure than he would be in a great city. When the newcomer is a legal aid clinic backed by the finances of a prosperous university, unusual care must be exercised if the adjustment to the established bar is to be accomplished without shock. All legal aid organizations must avoid competition with the bar. In legal aid clinics the difficulties of town and gown are always a possible obstacle. In the main this has been solved effectively. At Durham objections were raised by some critics first on the ground that it was a corporation practicing law. This was answered by the existence of a statute in North Carolina expressly permitting law schools to operate legal aid clinics. ${ }^{7}$ It was then argued that the clinic might handle cases for

${ }^{\circ}$ Some idea of the attitude of the bar may be gathered from reading the following clipping from the local newspaper (Durham Morning Herald of September 26, I93 I):

"Rumors of opposition by members of the Durham Bar Association to the legal aid clinic recently opened by the Duke University law school were crystallized yesterday afternoon in an informal meeting of the bar.

"Definite action by the Association relative to the clinic was withheld, however, pending the appearance of Dean Miller and Professor John Bradway, of the law school at a meeting of the association.

"Judge R. H. Sykes, speaking before the bar, said frankly he was not impressed by the idea of the clinic. He said he had learned from other members of the local bar that they were definitely opposed to it."

The following clipping from the Durham Morning Herald of October 2gth indicates the progress of the idea:

"A special committee of the Durham County Bar association appointed to study the legal aid clinic established by the Duke University law school, has recommended that the association recognize and cooperate with the clinic, subject to the supervision of a 'legal aid clinic committee' to be composed of five members of the local bar."

An editorial in the same issue of the above paper states:

"As forecast in these columns a few days ago, all that was needed to clear up the differences between the Durham bar and the Duke university law department over the question of clinics to be conducted by the school, was for the two to get together and discuss the matter. Whatever opposition there was melted away after representatives of the law school met with the local bar and outlined their plans. As soon as the two understood each other, their differences disappeared. The law school will go ahead with its plans for rendering a greater service than that rendered by just a law school, and will have the cooperation and good wishes of the members of the bar."

${ }^{7}$ N. C. Pub. Laws, 1931, c. 347 , p. 438 . 
clients where a fee was obtainable. This was met by the customary undertaking on the part of the clinic to confine its work to cases of persons who could not pay a fee and the subject matter of whose cases did not at any time warrant the payment of a fee. All legal aid organizations give this undertaking. A system of investigation was set up designed to separate applicants into two groups. It was agreed that if any case arose where a fee could be paid the applicant would be referred at once to the bar generally so that there might be no question of favoritism in distributing this business. ${ }^{8}$ Finally, a definite invitation was extended to each lawyer to come out to the University to inspect the work of the clinic and to take to his own office any case he found in which he thought the clinic should not continue its work, provided only that he would agree to give the same quality of service in the case that the clinic proposed to give. This proviso was solely for the protection of the client.

Eventually, a committee of the local bar association was appointed, composed of three members of the bar and two members of the law faculty of Duke University who were also members of the bar, to confer regarding specific problems that might arise. Thus, what might have been serious opposition on the part of the bar has developed into a process of cordial cooperation by which the lawyers refer to the clinic office ${ }^{9}$ cases of poor persons which the press of other business makes it inconvenient for them to handle, and the clinic refers to the bar generally cases outside its jurisdiction.

Of the three major preliminary obstacles, then, the geographical location has been found to present no real difficulties. The social problem has been met through a deepening of interest on the part of the social agencies and through a process of familiarizing the class of the public from which clinic clients come of its existence and the nature of its services. The problem with the legal profession has given way under a gradual process of organization through the state and now a spirit of cooperation exists.

${ }^{8}$ For material dealing with practical experience in this plan of coöperation between legal aid organizations and the bar in the transfer of business, see the Proceedings of the National Association of Legal Aid Organizations for 1923-24, p. 73 . See also Proceedings of the 1928 Convention, p. 37; Proceedings of the 1929 Convention, p. 33, and Reports of Committees for I929-30, p. 9.

The following statement is on the form used:

"I am referring this case to the Duke University Legal Aid Clinic because 1 have convinced myself that the applicant is not able to pay a fee. The reference is made with the understanding that if in the course of carrying on the case it appears a fee can be secured the Clinic will refer the case back to me." 
The clinic had 27 applications in October, 28 in November, ro in December, I4 in January, 22 in February, and 28 in March. In addition to these, a large number of problems were submitted by lawyers ${ }^{10}$ which required briefing of law, organization of facts and planning legal campaigns. This situation demonstrates conclusively that with all the obstacles confronting the work the public at large recognized a definite need; and when one compares this with the first few months in the law practice of the average young lawyer, the success is quite phenomenal.

\section{Educational Aims of the Clinic}

Our interest in this situation, however, is not confined to the public service given. Rather, we are concerned with the character of the clinical material. What is there in these cases which it is worthwhile for a law student to learn? In what respect is a student who has handled one of these cases better prepared for the responsibilities of a professional career? To answer this it is necessary that we should state the educational aims of the clinic.

A course in legal aid clinic work differs in many respects from other law school courses. There is a difference between class and clinic methods. The instructor is no longer on one side of the desk and the student on the other. Both face the client. Each sees clearly the strength and weakness of the other in dealing with actual situations. The team scrimmages after blackboard practice. So the student, having an intellectual grasp of the rules of law, sees them in operation and at the same time sees himself involved as a factor in every case.

The clinic course is designed to develop the student in respects not possible by the ordinary class analysis of cases. In other courses the student starts with the intention of finding the rule or rules of law applicable to certain facts. In the clinic the question is always - what is one to do for this client? In addition to seeing the case in the perspective of a logical system of scientific law, the student is required

10 The applications referred to were actual people coming to the office or, in a few cases, writing letters into the office. In addition to these, a large number of problems were submitted by lawyers so that clinic students had an opportunity to brief them with respect to North Carolina law. Plans are on foot for arranging to have the students who have briefed such matters as are to appear before the supreme court sit in at the argument with the lawyers who are trying the case. 
to see the case as a whole - as the client sees it, as the opposing counsel sees it, as the judge may see it. ${ }^{11}$

A case book, which is the starting point of other courses, presents a body of highly organized material in which the student's problem is made easier by the fact of chapter and section headings and the rules in the cases which precede and follow it. In practice there is no such organization other than the one the lawyer himself creates and applies to the series of clients who come into the office. In the

11 Suggested Outline of a Legal Case in Action

I. The process by which the client comes to the office

A. Legitimate methods of attracting business

r. Legitimate advertising

2. Legitimate solicitation

3. Law office organization to care for business

B. Methods of keeping contact with those persons who send business into the office

1. Former clients

2. Other interested persons

3. Interested groups

C. Statistics and record-keeping as to the source from which the case comes to the office

I. Reasons for keeping such records

2. Extent of such records

II. The First Interview

A. Winning the client's confidence

B. Keeping the office machinery moving

C. Taking hold of the interview

D. The problem of a retainer

III. Ascertaining the facts

A. Sources of facts

I. The client

2. Other persons

3. Public records

4. Other sources

B. Methods of ascertaining facts

I. By personal interview

2. By correspondence

3. By telephone conversation

4. By inspection of records or place

IV. Classifying the case

A. The need to translate the client's lay story into the field of legal thought

B. The preliminary classification

I. Cases in which there is no remedy or no complete remedy at law but in which there may be a remedy from other resources in the community - the social agencies, the medical profession, the clergy, the legislature

2. Classification of cases, where the law furnishes a remedy at least in part, in the general field of law in which they fall 
clinic the student learns what has led up to the highly organized material in the case book as well as what the client thinks about before and after the decision of the court has been rendered.

C. The final classification

I. Importance of refraining from making a final classification until all the facts are in

2. Classification in the particular portion of the field of law in which the case belongs

V. Determining the goal

A. Necessity of considering whether the client's objective will be secured best through law or elsewhere

B. If the best goal is in the field of law, the necessity of determining which of the several legal goals is the best

C. If the client desires a goal which the lawyer thinks is not ethical, the necessity for dealing with the problem

D. If there is a chance of securing a technical goal but no practical benefit, the need for dealing with the problem

E. If the client desires a goal and, on a question of business judgment alone, there is a difference of opinion on the part of the lawyer, the need for a solution

VI. Determining the means of reaching the goal

A. Conciliation

B. Arbitration

C. Litigation

D. Legislation

VII. Carrying out the plan of campaign

A. The technique involved in dealing with people

B. The technique of drawing legal documents

C. The technique of preparing a case for conciliation, arbitration, litigation, or legislation procedure

D. Necessity for flexibility in point of view to admit of modifying the original plan of campaign

E. Technique of withdrawing from an unfinished case

VIII. Closing the case

A. Technique of determining that all has been done that can be done and developing a defense of the action taken, if it should be necessary at any time to make an explanation

B. Technique of referring cases where some extra-legal agency or some other lawyer is to handle them

C. Technique of satisfying the client that all is done that can be done and that the lawyer's services are satisfactory

D. Evaluating the services, whether for the purpose of charging a fee or for securing credit points in the clinic work

E. Statistical work

1. Reasons for statistical work in closing a case

2. Extent and nature of the records to be kept

The reader will note that section $I$ is approached by some of the material given in the course in legal ethics, where the student is advised that certain types of advertising and solicitation are contrary to the ethical principles of the bar. Sections II, III, IV, V, and VI are considered in a handbook used by the clinic students at Southern California and Duke Law Schools. There is a textbook in process of preparation dealing with phases of these points. Sections IV-C, part of V substantive, and VII are 


\section{Sources of Legal Aid Business}

One of the most interesting phases of law practice is the process by which the individual lawyer builds up a lucrative clientele. $\mathrm{Ob}$ viously, few members of the bar feel at liberty to discuss frankly the technique involved. At the same time, there are few things which bother the young lawyer more, unless he proposes to become for all time a subordinate in a law office or an employee of the legal department of a corporation. It is doubtful if there is any period in the life of a young lawyer more subject to the temptation to do unethical things than the nerve-wracking years while he is waiting for business to come in to him. The clinic as a law school course offers the student the unique opportunity of ascertaining the sources from which business comes to the clinic, and thereby suggests to him the contacts he should make in his own community if he expects to gather a group of clients of his own. ${ }^{12}$

covered by the other law school conrses. Section VIII again is discussed in the clinic Handbook.

${ }^{12}$ Legal aid societies have adopted, through their National Association of Legal Aid Organizations, a standard classification of source of case. During 1929, which is the last year for which detailed statistics are available, there were 125,769 cases recorded. They are distributed by percentages as follows:

\section{Data as to Case - Source}

I. Federal Government

PER CENT

A. Federal courts

B. Federal officers

I. Shipping Commissioner

2. U. S. District Attorney

3. Immigration Bureau

4. Veterans' Bureau

5. Others

II. State and County Government

A. Highest court

B. Court of general jurisdiction

C. Probate court, etc.

D. Industrial accident board

E. District Attorney

F. Other State Officers

I. Labor Bureaus

2. Insurance Commissioner

3. Banking Commissioner

4. Others

III. Local Government

A. Local courts

I. Municipal Court

2. Small Claims Court

3. Domestic Relations Court

4. Juvenile Court 
The clinic student also has an opportunity of making contacts with social agencies. In conducting a case in which a legal aid organization and a social agency are both interested, each group benefits by an understanding of the principles and ideals underlying the work of the other. At a time when so much emphasis in law teaching is placed upon giving the student a social viewpoint so that he may be oriented not merely with respect to the law but with respect to the community of which he and the law are parts, this further opportunity of the student for the application of principles in a practical way is one that must not be overlooked.

B. Local Prosecutor

PER CENT

C. Police

D. Other local officers

I. Mayor

2. Health Department

3. Board of Education

4. Others

IV. Foreign Consuls

V. Legal Associations
A. Lawyers
B. Bar Associations
C. Legal Aid Associations

VI. Medical - Doctors and Hospitals

VII. Religious - Churches and Clergy

VIII. Social Agencies
A. Associated Charities
B. Red Cross
C. Children's Aid Society
D. American Legion
E. Salvation Army
F. Others

IX. Business and Industry
A. Employers
B. Labor Unions
C. Others
I. Banks
2. Insurance Companies
3. Employment Agencies
4. Others

X. Publicity
A. Newspapers
B. Others

XI. Individuals
A. Previously served by-society
B. Referred by another client
C. Direct application
D. Member of society
E. Private Individuals
F. Others 
At the same time, the constant contact with cases in which other lawyers are involved gives the clinic student at least some notion of what is included in the field of etiquette among members of the bar.

Thus, in a great variety of ways a single clinic case tends to eliminate from the mind of the student that sense of strangeness which is perhaps the greatest single obstacle to success at the bar in the early years of practice.

The general purpose of the case method is to build in the student, by contact with original case material, hypothetical problems, and class discussions, a tough mental fiber so that he will think the way a lawyer thinks. Undoubtedly, the analytical point of view is essential to the legal mind, but it does not follow necessarily that everyone who has a good analytical mind is without more a good practicing lawyer. Other strands of mental and moral fiber must be toughened. The student must be taught to think constructively as well as analytically. But he must be taught to act as well as to think. He must learn how to react to problems which involve temptations to do things that are unethical. He must come to realize that law is only one method of solving human problems and not always the most effective method. He must gain judgment, experience, poise, and a professional manner. He must fit himself and his learning into a law office and a community as by an apprenticeship. The clinic course is aimed in this direction.

\section{Nature and Results of the Course}

It is difficult to tell how far the course succeeds in its aims. Perhaps in time the experiences of law students may be collected on a wide scale and analyzed with this in view. Personal observation has convinced the writer that perhaps fifty per cent of the students who have come under his eye would be happier elsewhere than in the law. If they could be brought to realize their ineptitude, much delay, even tragedy, might be saved them. The tests of the course approximate the conditions under which employers, judges, clients, and the general public will relegate the young lawyer to his particular level at the bar. . An observing student will test himself in respect to the work.

Particularly interesting are the groupings which may be made of the class. Some men become disgusted with general practice and learn their aptitude for a specialty. The trial lawyer, the office lawyer, the business getter, the briefing clerk become aware of themselves. To the instructor are apparent unreliability, inexactness, un- 
willingness to accept responsibility, tactlessness, mental stagnation, inability to visualize legal form, lack of imagination in anticipating and preparing for contingencies, uncertainty of judgment. In due course, there is in the clinic a sifting process which should produce material of interest to admissions committees of bar associations.

One respect in which the clinic course differs materially from other law school courses is in the length of time it takes to develop the student's viewpoint. When one starts to study the law it may take him a year or two to master the case method, but he begins at once to acquire information about specific parts of the law. An examination covers only the parts prescribed for study. In the clinic work the student's very first case may present a problem of the first magnitude for which he has had no special preparation; he must flounder through with whatever aid is possible.

If the student has the character, he gradually seasons; otherwise, he fails. There are men with inferiority complexes, timid men, men who are in law school only because of their families and who have not found themselves, men so aggressive that they frighten the clients, lazy men who try to practice law by hearsay. The process of seasoning these men is essentially an individual one. Education in the mass is not a satisfactory way to conduct cases in which real clients have vital interests. The process must go on with respect to each act the student does. Some one should overhear and analyze with him what he says to the client and what the client replies; some one should censor his conferences, his correspondence, his researches as to the law. His work must be criticized and his weaknesses pointed out. There is a vast amount of information about law practice which becomes part of the subconscious mental equipment of all good lawyers within a few years after they are admitted to the bar. If we can devise a systematic method for imparting it to the student, he will make his adjustment just that much more quickly after he steps out of law school.

Illustrations of the Educational Possibilities of Clinical Material

The following illustrations are taken at random from among the first twenty cases arising in the Duke Legal Aid Clinic. Similar examples could be secured from any other legal aid clinic but as the purpose of this article is to deal with the situation in the smaller communities, it seems essential that the illustrations come thence. The 
facts are modified just enough so that there shall be no chance of violating confidential relationships between attorney and client.

In one case, two negroes, a man and a woman, appeared in the office and the woman began to relate her troubles. She was a widow. Her husband had owned a piece of land during his lifetime which he had acquired prior to his marriage. He had built a house on the property and had lived in it with her for a number of years. After his death she continued to live in the place and had it insured against loss by fire. She made out her application for the insurance in her own name as owner. After a fire the insurance company declined to pay her claim for loss on the ground that she was not the owner of the property but, under the law of the state dealing with intestacy, her husband's family also had an interest, and that her application contained a false statement of a material fact. At this stage of the interview the man announced that his purpose in bringing the claimant to the clinic was to ascertain whether or not she had any rights in the insurance policy. If she had, then he would divorce his present wife and marry the widow.

The case presented a number of problems. It was outside the legal aid jurisdiction because of the fact that if the case was successful a fund would be produced out of which a fee could be secured. But the students who participated in the work had the experience of conferring with real clients about a real case. They went through the mental processes of classifying the client's disorganized story with regard to whether there was any legal problem at all and then locating it in a given field of law. They had to make up their minds, of course, under the supervision of a member of the bar, as to the proper goal in the case toward which they would work to secure the best interests of the client and the best method of reaching the goal. Carrying out the plan of campaign was beyond the scope of their authority as a fee could be paid, but for the better part of an hour they went through the motions of practicing law in a stage of the case they would not see in their case books. Not only did they have to exercise legal judgment in deciding how to advise the woman as to her legal problems but it was their responsibility also to determine as a matter of ethics how to deal with a man who wished to divorce his wife and marry some other woman because she had a chance of getting a little money. In this case the human, the social, and the legal problems were nicely mingled.

In a second case, a woman appeared asking that we issue warrants for a judge and two lawyers on the ground that they had involved 
her in a mortgage transaction by securing her signature when she thought she was signing an affidavit. She further alleged that when one phase of the matter had come up in court one of the lawyers had failed to appear and the matter had gone against her by default. The matter had been referred to the clinic by a member of the bar so there was not much question that it was a proper case to handle under our rules.

The question was - what should we do? To refer the matter to the Grievance Committee of the Bar Association might give countenance to the thought that the clinic was lending its name to the persecution of members of the bar. To do nothing would have been to confess inability to function in the presence of a difficult problem. One student asked to be relieved from the responsibility of the case on the ground that he might impair his future standing with the bar. Another student accepted the case with the remark that he did not like to do that sort of work but he was not going to start his career at the bar by dodging work merely because it might be unpleasant.

He had a chance to learn the facts by conference with the client and witnesses, by inspection of court records, and reading through piles of correspondence. He visited the lawyers who were accused, made friendly contacts with them, explained the disinterested position of the clinic, and learned the other side of the case. He then weighed the two stories, one against the other, and decided in favor of the lawyers. Finally, he had the task of dealing with the applicant and telling her that she had no case at law. Of course, this was all under supervision, but enough leeway was given the student so that he could feel a sense of responsibility for the outcome of the case. Law, ethics, legal etiquette, the client's mental condition, and other factors were involved even though the case never rose to the place where it could be reported in a case book.

In another case, a married man became acquainted with a young girl, fifteen years of age. He persuaded her to run away with him, making her believe that he was single. On the first day of their flight they crossed the state line and the man produced a bit of paper on which he had written certain statements which he told the girl constituted a marriage license. She believed this story and thought that she was his lawful wife, although no ceremony recognized by law had taken place. They then cohabited in three or four other states, in the course of which time the man stole an automobile. In none of the states was a common law marriage recognized as valid. Finally, they were formally married in South Carolina and, at the suggestion of a 
policeman, who believed that by this process an indictment might be secured for bigamy, they cohabited in the state of North Carolina. The defendant was arrested but was released and his whereabouts was unknown.

This was obviously a legal aid case because of the financial condition of the young girl and the fact that she was absolutely without funds to raise the child which had been born two months previously. Here the students had the opportunity of determining which one of a dozen or more legal possibilities was the best in the particular case. Prosecution under the Mann (White Slave) Act, prosecution for bigamy, prosecution for non-support, civil procedure to have the marriage annulled, the legitimating of the child and its adoption were among the possible solutions. The students then received excellent training, not merely in conferring with the client, who was a shy, timid young girl, tremendously embarrassed by her experience, but were confronted with the highly professional problem of determining the goal of this case on the basis of what was best for the client. As the situation subsequently worked out, the students received training in drawing papers in an annullment case, in taking depositions of the first wife in a distant state, and in proceeding before the court in forma pauperis. They also had a chance to sit by while the case was being tried in court.

In still another case, an old negro appeared as a client. He owned a small piece of land, a part of which he farmed. In order to secure money to raise his crop, he signed a note secured by a mortgage in the amount of $\$ 475$, of which he received only $\$ 400$. Shortly thereafter, a man drove up to his door and asked him if he was going to be able to meet his payments on the note. He doubted his ability to do so and the man went away, promising to advise him before anything was done. After some time, another man appeared and asked whether the farmer desired to rent the farm. He replied that he owned it and saw no reason for renting. The visitor declared that he had purchased it at a sheriff's sale but would be glad to make every reasonable adjustment to rent it to the former owner. The old man contended that he had received no notice whatsoever of this foreclosure proceeding. It appeared under the statute that no personal notice need be served on the maker of the note in such case. All that was necessary was that notice of the foreclosure proceeding be published a certain number of times in a newspaper printed in the country. Invariably, this sort of legal advertising was placed with a newspaper of comparatively limited circulation which even a well educated person would not be likely to see. The client could not read. 
In this case the student searched the court records to find out whether the foreclosure proceeding had been conducted according to the rules. Incidentally, he learned a good deal about such proceedings. There was an opportunity to investigate the question of whether the client had been the subject of usury. Here was a chance to make a suggestion to the next legislature. It would seem as though any person who signs a note in such a case should have more specific notice of a foreclosure than mere publication in any newspaper published in the country. This result could be brought about only by remedial legislation. The case was particularly interesting because there were many features calling for the sympathy of the student on the behalf of the client, and yet, except by legislation, there was nothing to be done because the law had been complied with.

So, in just four cases we discover opportunities for training in interviewing clients, adjustment of a case out of court, litigation, and legislation. Other questions arise that are equally important and interesting. In one case the clinic has been asked for an advisory opinion in connection with the validity of a California marriage where the parties were in London. In another case a request has been made that we investigate an alleged swindle in connection with an estate settled in Syria. This requires finding for the client a reputable attorney in a little village in Syria. The process is one which is possible because of an international conference regarding legal aid work sponsored by the League of Nations in $1923 .{ }^{13}$ Numerous students in other departments of the University appear with personal problems of one sort or another, including automobile accidents and family problems in which investigation of facts is the most important clinical aspect. It is difficult to conceive of a case which does not present some problem worthy of study. All that is required to produce educational material from clinic problems is a real interest on the part of those operating the organization, and the use of a little imagination.

${ }^{13}$ In 1923 an International Conference of Legal Aid work was called by the League of Nations. The work of this conference is described in the March, 1926, volume of Annals of the American Academy of Political and Social. Science, 167, "International Legal Aid Work," by Reginald Heber Smith. See also in this regard, Bulletin No. 398 of the U. S. Bureau of Labor Statistics, "The Growth of Legal Aid Work in the United States," ch. I3, p. 7 I ff. (1926).

The results of this conference were the production of a large volume of material entitled "Legal Aid for the Poor," Geneva, 1927, publications of the League of Nations, V, Legal, 1927, V 27, containing: Part I - "Laws, Regulations, and Treaty Provisions regulating Legal Aid in Certain Countries"; Part 2- "Law of Agencies for Legal Aid established in Certain Countries"; Part 3- "List of Authorities or Persons appointed in certain countries to answer enquiries from abroad." 


\section{Conclusion}

From the foregoing it will appear that clinic work in one sense is a new departure in legal education. In another sense it is merely a return to fundamentals by taking into the law school the best elements of the apprenticeship system. Probably the things we are most anxious to produce in the process of legal education are a tough mental fiber, well rounded as to rules of law and their application, a broad social vision, and a strength of character in the broadest sense. The case method develops one of the most essential elements, but it requires actual contact with real situations outside of books to round out the toughness of a man's moral fiber and to give the instructor a chance to observe his character under fire. The community is demanding today certain qualifications in a lawyer, perhaps broader and higher than ever before. It is not enough, then, that law schools prepare men to be merely research assistants or to write briefs in large law offices. And this is especially true of a law school which is not preparing men exclusively for practice in New York City or other large centers.

Leadership at the bar demands analytical ability and a great many other things. The clinic organization essentially tests a man for these other qualities of leadership. In time it may be that no person will be admitted to the practice of the law until he has passed through a period of apprenticeship or interneship in legal clinic work or in a good law office which has the time and inclination to give him equivalent training. If the legal aid clinic can bring to the attention of these younger men coming to the bar a sense of the value which attaches to their ability to cope with life as well as their ability to cope with a complicated legal problem, it will have made a distinct contribution to the efforts which the bar is putting forth to regain its prestige and position of eminence of earlier years. That for this purpose there is available ample clinical material in rural as well as in urban communities, and that a way can be found to surmount such obstacles as present themselves cannot be questioned. 